\title{
Fast sediment underplating and essentially coeval juvenile magmatism in the Ordovician margin of Gondwana, Western Sierras Pampeanas, Argentina
}

\author{
César Casquet ${ }^{\mathrm{a}, *}$, Carlos W. Rapela ${ }^{\mathrm{b}}$, Robert J. Pankhurst ${ }^{\mathrm{c}}$, Edgardo Baldo ${ }^{\mathrm{d}}$, Carmen Galindo ${ }^{\mathrm{a}}$, \\ Cristopher M. Fanning ${ }^{\mathrm{e}}$, Juán Dahlquist ${ }^{\mathrm{d}}$ \\ ${ }^{a}$ Departamento de Petrología y Geoquimica, Universidad Complutense - IGEO (CSIC), 28040 Madrid, Spain \\ ${ }^{b}$ Centro de Investigaciones Geologicas (CONICET-UNLP), 1900 La Plata, Argentina \\ c Visiting Research Associate, British Geological Survey, Keyworth, Nottingham NG12 5GG, United Kingdom \\ d CICTERRA (CONICET-UNC), 5000 Córdoba, Argentina \\ e Research School of Earth Sciences, The Australian National University, Canberra ACT 0200, Australia
}

Keywords:

Famatinian magmatic arc

Juvenile magmatism

$\mathrm{U}-\mathrm{Pb}$ SHRIMP zircon geochronology

Gondwana

Sierras Pampeanas

\begin{abstract}
A B S T R A C T
Metasedimentary high-pressure upper amphibolite facies gneisses $\left(1.2 \pm 0.1 \mathrm{GPa}\right.$ and $\left.780 \pm 45^{\circ} \mathrm{C}\right)$ at Las Chacras, Sierra de Valle Fértil, are tectonically juxtaposed to the westernmost parts (outboard) of the Famatinian (Early Ordovician) magmatic arc, which underwent syn-plutonic middle crust high-grade metamorphism at lower pressure. U-Pb SHRIMP zircon data suggest that the gneisses contain Famatinian igneous detritus, so that their sedimentary protoliths were probably deposited in a forearc basin and then rapidly underthrust and accreted to the lower crust of the arc, essentially coevally with arc magmatism at $468 \pm 4 \mathrm{Ma}$. Chemically and isotopically juvenile garnetiferous amphibolites within the gneisses are recognised as representing the most primitive magmas so far observed in this belt, which has often been considered to be a continental arc derived from isotopically mature sources. This is consistent with the idea that at least part of the dominant Famatinian magmatism originated in depleted mantle but was heavily contaminated by crustal components.
\end{abstract}

\section{Introduction}

Processes within the lower crust of magmatic arcs along active continental margins are poorly known because this setting is currently inaccessible and is poorly exposed in the geological record. The associated magmatism often exhibits a chemical contribution from the continental crust and in consequence the possible involvement of subduction-related juvenile magmas cannot be confirmed. Two alternative processes may be involved. One is that the crustal component is incorporated into juvenile mantle-wedge derived basalts in the deep crust of the arc or at the crust-mantle transition (e.g., Hildreth and Moorbath, 1988). Subsequent magmatic diversification takes mainly place in the deep lower crust of the arc, resulting in intermediate to acidic magmas that are emplaced in the middle to upper crust or extruded (e.g., Annen et al., 2006). The main alternative involves direct partial melting of less depleted mantle or older crustal protoliths in the deep crust of the arc (e.g., Pankhurst et al., 2000; Chappell and White, 2001). Identifying input of juvenile magmas at the root of the magmatic arc is thus important to the petrogenesis of subductionrelated magmatism (e.g., Ram Mohan et al., 2012; Straub and Zellmer, 2012). We show that in the Ordovician Famatinian magmatic arc of

\footnotetext{
* Corresponding author. Tel.: + 34 913944908; fax: + 3491542535.

E-mail address: casquet@geo.ucm.es (C. Casquet).
}

western Argentina outboard sediments were buried and accreted to the root of the arc essentially coevally with the magmatic event. They were injected by almost contemporaneous juvenile magmas, thus providing evidence for mantle involvement in the arc magmatism.

\section{Geological setting}

The Early Ordovician Famatinian arc along western South America (Fig. 1) consists of intermediate to acid, I- and S-type plutons and volcanic rocks (Pankhurst et al., 1998, 2000; Dahlquist et al., 2008; Otamendi et al., 2009, 2012) and has been unanimously related to subduction along the western margin of Gondwana between ca. 495 and $465 \mathrm{Ma}$ (e.g., Chernicoff et al., 2010). The granitoids display a significant crustal isotopic signature (initial ${ }^{87} \mathrm{Sr} /{ }^{86} \mathrm{Sr}$ mostly $>0.707 ; \varepsilon N d t$ mostly $<-4$ ).

The Sierra de Valle Fértil represents the outermost part of the Famatinian arc (Fig. 1). It consists mainly of elongated bodies of gabbro, tonalite, granodiorite and granite (the Valle Fértil plutonic suite, VFPS), largely concordant with foliation of the host rocks. Field relations suggest that gabbros are the oldest intrusive rocks with tonalites and granodiorites being slightly younger. The host rocks are medium pressure upper amphibolite to granulite facies metasedimentary rocks $\left(0.6 \pm 0.1 \mathrm{GPa}, 800 \pm 40^{\circ} \mathrm{C}\right.$; Otamendi et al., 2008), predominantly metapelitic sillimanite-garnet $( \pm$ cordierite) migmatitic gneisses of middle to late Cambrian age (Casquet et al., 2011; Cristofolini et al., 


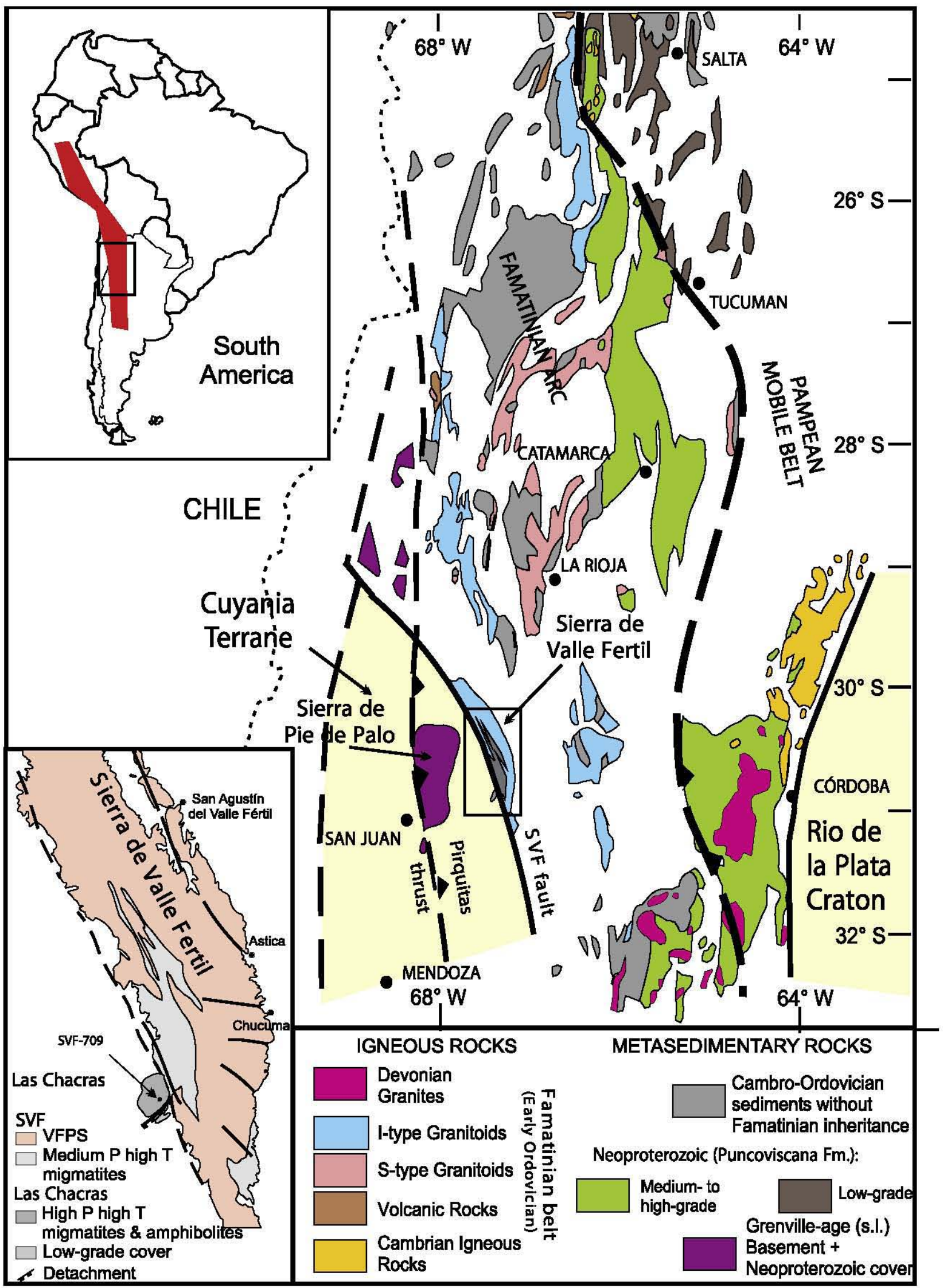

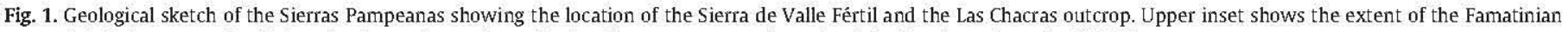
orogenic belt in western South America. Lower inset shows the Las Chacras outcrop enlarged and the location of sample SVF-709. 
2012) and minor metacarbonates and calc-silicate rocks of unknown age. Igneous petrology and U-Pb SHRIMP zircon dating of the igneous and metamorphic rocks were included in Pankhurst et al. (2000), Rapela et al. (2001) and Baldo et al. (2001), but more detailed studies of geology, igneous petrology, metamorphism and geochronology have since been published (Otamendi et al., 2008; Gallien et al., 2009; Otamendi et al, 2009; Ducea et al, 2010; Otamendi et al, 2012). Magmatism and metamorphism here took place within a narrow time span at ca. $470 \mathrm{Ma}$ (Ducea et al., 2010; Casquet et al., 2011). Otamendi et al. (2012) have recently proposed that the Famatinian plutonic rocks of the Sierra de Valle Fértil originated by crustal melting and hybridisation with more primitive magmas derived from the subduction mantle wedge.

Loma de Las Chacras is a small circular outcrop of metamorphic rocks tectonically separated from the rest of the Sierra de Valle Fértil by a Cenozoic fault that reactivated older ones (Fig. 1). A core of felsic kyanitegarnet migmatitic gneisses and garnet amphibolites (Vujovich et al., 1994; Baldo et al., 2001) is separated by a low-angle extensional detachment from overlying low-grade garnet schists and quartzites. The amphibolites represent swarms of former dykes, some several metres thick, transposed into parallelism with the foliation of the host migmatite and often folded with axial planes parallel to main foliation. Vujovich et al. (1994) argued on geochemical grounds that their probable tectonic setting was an island arc or attenuated crust.

\section{Petrography and P-T conditions of metamorphism}

Migmatitic gneisses at Loma de Las Chacras are layered (stromatites). Representative sample SVF-707 was chosen for thermobarometry (see Table 1). Leucosomes contain $\mathrm{K}$-feldspar $\left(\mathrm{Or}_{82}\right)$ quartz and plagioclase $\left(\mathrm{An}_{17-30}\right)$; there are smaller amounts of biotite $\left(\mathrm{X}_{\mathrm{Mg}}=0.58\right)$, garnet $\left(\mathrm{Alm}_{62}, \mathrm{Py}_{20}, \mathrm{Grs}_{6.5}, \mathrm{Sps}_{6}\right)$, kyanite and euhedral zircon, apatite and tourmaline. The melanosome consists of biotite $\left(\mathrm{X}_{\mathrm{Mg}}=0.61\right)$, kyanite, garnet, magnetite/ilmenite \pm quartz \pm plagioclase $\left(\mathrm{An}_{25}\right)$. Late muscovite is recognised. Garnet porphyroblasts in the melanosome are compositionally zoned with increasing $\mathrm{Fe}, \mathrm{Mg}$, and $\mathrm{Ca}$ towards the rim and decreasing $\mathrm{Mn}$ and $\mathrm{Fe} / \mathrm{Fe}+\mathrm{Mg}$ ratio (core: $\mathrm{Fe} / \mathrm{Fe}+\mathrm{Mg}=0.75$, $\mathrm{Grs}=0.8, \mathrm{Sps}=19 ; \mathrm{rim}: \mathrm{Fe} / \mathrm{Fe}+\mathrm{Mg}=0.73 \mathrm{Grs}=5.6, \mathrm{Sps}=7.3$ ), suggesting that growth took place with increasing temperature and pressure. High-P upper amphibolite facies peak conditions of $1.2 \pm 0.1 \mathrm{GPa}$ and $780 \pm 45^{\circ} \mathrm{C}$ were obtained from the garnet rim composition and groundmass plagioclase and biotite, using Thermocalc in the PT-average mode (Powell et al., 1998). These conditions are indicative of a medium T/P ratio metamorphism close to Barrovian.

The garnet amphibolites consist of pargasitic hornblende $\left(\mathrm{X}_{\mathrm{Mg}}=0.6\right.$, $\mathrm{Si}=6.4)$, garnet $\left(\mathrm{Gr}_{30-36}, \mathrm{Alm}_{46-48}\right)$, plagioclase $\left(\mathrm{An}_{20-23}\right)$, quartz, epidote $\left(\mathrm{Ps}_{11-14}\right)$ and titanite, with garnet porphyroblasts up to several centimetres. Titanite shows up to $1.4 \% \mathrm{Al}_{2} \mathrm{O}_{3}$.

\section{U-Pb SHRIMP geochronology}

$\mathrm{U}-\mathrm{Pb}$ SHRIMP zircon geochronology was carried out on a high-grade garnet-kyanite migmatitic gneiss (SVF-709) from Loma de Las Chacras, using SHRIMP I (17 spots) and SHRIMP II ( 9 spots) at the Research School of Earth Sciences, The Australian National University, Canberra, Australia (see Table 2). Many of the zircon grains are detrital prismatic igneous zircon with oscillatory zoning (Fig. 2A), of both Famatinian age (between $466 \pm 6 \mathrm{Ma}$ and $481 \pm 6 \mathrm{Ma}$, with a weighted mean of $472 \pm 5 ; \mathrm{n}=7$, MSWD $=1.0$ ) and older (between 570 and $1650 \mathrm{Ma} ; \mathrm{n}=14$ ). The first group (and most of the latter) has $\mathrm{Th} / \mathrm{U}$ values between 0.3 and 1.1 which may be regarded as typical of igneous zircon. In addition we recognise zircon formed subsequently, either as unzoned overgrowths or as needles with low cathodoluminiscence $(\mathrm{CL})$; all of these have very low $\mathrm{Th} / \mathrm{U}$ values $(<0.02)$ characteristic of metamorphic zircon: the needles probably formed in low-Th leucosomes. The ages of the metamorphic zircons ( $\mathrm{n}=8$ ) range from $392 \pm 4$ to $469 \pm 5$ Ma. If the lowest

Table 1

Electron microprobe data for minerals used in thermobarometric calculation.

\begin{tabular}{|c|c|c|c|c|c|c|c|c|}
\hline \multirow{3}{*}{$\begin{array}{l}\text { Mineral site analysis } \\
\text { wt.\% }\end{array}$} & \multicolumn{3}{|l|}{ Garnet } & \multicolumn{2}{|l|}{ Biotite } & & \multicolumn{2}{|l|}{ Plagioclase } \\
\hline & Rim in leucosome & Core & Rim in Melanosome & Included in Grt & Matrix & & Contact with Grt & Contact with Grt \\
\hline & SVF $707-13$ & SVF $707-8$ & SVF $707-1$ & SVF $707-22$ & SVF $707-24$ & & SVF 707-6 & SVF $707-19$ \\
\hline $\mathrm{SiO}_{2}$ & 38.54 & 38.03 & 37.83 & 37.94 & 36.87 & & 60.74 & 61.55 \\
\hline $\mathrm{TiO}_{2}$ & $<0.08$ & $<0.08$ & 0.05 & 2.43 & 2.51 & & 0 & 0.01 \\
\hline $\mathrm{Al}_{2} \mathrm{O}_{3}$ & 22.07 & 22.03 & 23.09 & 18.39 & 17.89 & & 24.18 & 23.73 \\
\hline $\mathrm{Cr}_{2} \mathrm{O}_{3}$ & $<0.06$ & $<0.06$ & 0 & 0 & 0 & & 0 & 0 \\
\hline $\mathrm{FeO}$ & 28.31 & 28.23 & 28.2 & 13.51 & 15.44 & & 0 & 0 \\
\hline $\mathrm{MnO}$ & 3.18 & 5.65 & 3.93 & 0.08 & 0.13 & & 0.024 & 0.02 \\
\hline MgO & 5.51 & 5.3 & 5.61 & 13.06 & 11.82 & & 0 & 0 \\
\hline $\mathrm{CaO}$ & 3.43 & 1.93 & 2.68 & 0 & 0 & & 5.28 & 5.07 \\
\hline $\mathrm{Na}_{2} \mathrm{O}$ & 0 & 0.02 & 0 & 0.2 & 0.17 & & 8.6 & 8.7 \\
\hline $\mathrm{K}_{2} \mathrm{O}$ & 0 & 0 & 0 & 9.91 & 9.7 & & 0.33 & 0.19 \\
\hline $\mathrm{F}$ & 0 & 0 & 0 & 0 & 0 & & 0 & 0 \\
\hline $\mathrm{Cl}$ & 0 & 0 & 0 & 0.06 & 0.05 & & 0 & 0 \\
\hline $\mathrm{H}_{2} \mathrm{O}$ & 0 & 0 & 0 & 4.46 & 4.37 & & 0 & 0 \\
\hline Total & 101.21 & 101.41 & 101.41 & 100.02 & 98.96 & & 99.15 & 99.32 \\
\hline Oxygen & 24 & 24 & 24 & 18 & 18 & & 32 & 32 \\
\hline $\mathrm{Si}$ & 2.99 & 2.97 & 2.93 & 5.08 & 5.05 & & 10.89 & 10.99 \\
\hline $\mathrm{Ti}$ & 0 & 0.03 & 0.03 & 0.25 & 0.26 & & 0 & 0 \\
\hline Al & 2.02 & 1.99 & 2.1 & 2.9 & 2.88 & & 5.1 & 4.99 \\
\hline $\mathrm{Cr}$ & 0 & 0 & 0 & 0 & 0 & & 0 & 0 \\
\hline $\mathrm{Fe}^{2+}$ & 1.84 & 1.75 & 1.83 & 1.51 & 1.77 & & 0 & 0 \\
\hline $\mathrm{Mn}$ & 0.21 & 0.37 & 0.26 & 0.01 & 0.02 & & 0 & 0 \\
\hline $\mathrm{Mg}$ & 0.64 & 0.62 & 0.65 & 2.61 & 2.41 & & 0 & 0 \\
\hline $\mathrm{Ca}$ & 0.29 & 0.16 & 0.22 & 0 & 0 & & 1.01 & 0.97 \\
\hline $\mathrm{Na}$ & 0 & 0 & 0 & 0.05 & 0.05 & & 2.99 & 3.01 \\
\hline K & 0 & 0 & 0 & 1.69 & 1.69 & & 0.07 & 0.04 \\
\hline $\mathrm{XMg}$ & & & & 0.63 & 0.58 & $\mathrm{Ab}$ & 73.3 & 74.8 \\
\hline Хрур & 22.16 & 21.26 & 22.62 & & & An & 24.8 & 24.1 \\
\hline Xalm & 60.64 & 60.3 & 60.61 & & & Or & 1.8 & 1.1 \\
\hline Xgro & 5.13 & 0.8 & 2.98 & & & & & \\
\hline Xsps & 7.27 & 12.86 & 8.99 & & & & & \\
\hline
\end{tabular}


Table 2

Summary of SHRIMP U-Pb zircon results for sample SVF 709

\begin{tabular}{|c|c|c|c|c|c|c|c|c|c|c|c|c|c|c|c|c|c|c|c|c|c|c|}
\hline \multirow{2}{*}{$\begin{array}{l}\text { Grain. } \\
\text { spot }\end{array}$} & \multirow{2}{*}{$\begin{array}{l}\mathrm{U} \\
(\mathrm{ppm})\end{array}$} & \multirow{2}{*}{$\begin{array}{l}\text { Th } \\
\text { (ppm) }\end{array}$} & \multirow{2}{*}{$\begin{array}{l}\text { Th/ } \\
\mathrm{U}\end{array}$} & \multirow{2}{*}{$\begin{array}{l}{ }^{206} \mathrm{~Pb}^{*} \\
(\mathrm{ppm})\end{array}$} & \multirow{2}{*}{$\begin{array}{l}{ }^{204} \mathrm{~Pb} / \\
{ }^{206} \mathrm{~Pb}\end{array}$} & \multirow[t]{2}{*}{$\mathrm{f}_{206} \%$} & \multicolumn{4}{|c|}{ Total ratios } & \multicolumn{6}{|c|}{ Radiogenic ratios } & \multirow[t]{2}{*}{$\mathrm{r}$} & \multicolumn{4}{|c|}{ Age (Ma) } & \multirow[t]{2}{*}{ \%Disc } \\
\hline & & & & & & & $\begin{array}{l}{ }^{38} \mathrm{U} / \\
{ }^{206} \mathrm{~Pb}\end{array}$ & \pm & $\begin{array}{l}{ }^{07} \mathrm{~Pb} / \\
{ }^{206} \mathrm{~Pb}\end{array}$ & \pm & $\begin{array}{l}{ }^{206} \mathrm{~Pb} / \\
{ }^{238} \mathrm{U}\end{array}$ & \pm & $\begin{array}{l}{ }^{207} \mathrm{~Pb} / \\
{ }^{235} \mathrm{U}\end{array}$ & \pm & $\begin{array}{l}{ }^{207} \mathrm{~Pb} / \\
{ }^{206} \mathrm{~Pb}\end{array}$ & \pm & & $\begin{array}{l}{ }^{206} \mathrm{~Pb} / \\
{ }^{238} \mathrm{U}\end{array}$ & \pm & $\begin{array}{l}{ }^{207} \mathrm{~Pb} / \\
{ }^{206} \mathrm{~Pb}\end{array}$ & \pm & \\
\hline 1.1 & 547 & 171 & 0.31 & 35.6 & 0.000305 & 0.47 & 13.198 & 0.145 & 0.0602 & 0.0007 & 0.0754 & 0.0008 & & & & & & 468.7 & 5.0 & & & \\
\hline 2.1 & 391 & 2 & 0.01 & 25.4 & 0.000361 & 0.33 & 13.219 & 0.150 & 0.0591 & 0.0007 & 0.0754 & 0.0009 & & & & & & 468.6 & 5.2 & & & \\
\hline 3.1 & 780 & 6 & 0.01 & 50.4 & 0.000060 & 0.10 & 13.297 & 0.143 & 0.0571 & 0.0005 & 0.0751 & 0.0008 & & & & & & 467.0 & 4.9 & & & \\
\hline 4.1 & 137 & 100 & 0.73 & 8.9 & 0.000058 & 0.48 & 13.279 & 0.178 & 0.0603 & 0.0012 & 0.0749 & 0.0010 & & & & & & 465.9 & 6.1 & & & \\
\hline 5.1 & 680 & 12 & 0.02 & 44.0 & - & $<0.01$ & 13.270 & 0.144 & 0.0564 & 0.0005 & 0.0754 & 0.0008 & & & & & & 468.3 & 5.0 & & & \\
\hline 6.1 & 365 & 3 & 0.01 & 23.8 & 0.000221 & 0.45 & 13.201 & 0.152 & 0.0601 & 0.0012 & 0.0754 & 0.0009 & & & & & & 468.6 & 5.3 & & & \\
\hline 6.2 & 682 & 18 & 0.03 & 54.6 & 0.000475 & 0.77 & 10.731 & 0.120 & 0.0654 & 0.0008 & 0.0925 & 0.0011 & & & & & & 570.2 & 6.2 & & & \\
\hline 7.1 & 213 & 71 & 0.33 & 47.1 & - & $<0.01$ & 3.890 & 0.046 & 0.1010 & 0.0008 & 0.2572 & 0.0031 & 3.601 & 0.052 & 0.1015 & 0.0008 & 0.830 & 1476 & 16 & 1652 & 15 & 11 \\
\hline 7.2 & 1915 & 174 & 0.09 & 176.8 & 0.000035 & 0.53 & 9.307 & 0.100 & 0.0658 & 0.0003 & 0.1069 & 0.0012 & & & & & & 654.6 & 6.9 & & & \\
\hline 8.1 & 748 & 4 & 0.01 & 41.4 & 0.001213 & 2.65 & 15.532 & 0.171 & 0.0759 & 0.0008 & 0.0627 & 0.0007 & & & & & & 391.9 & 4.3 & & & \\
\hline 8.2 & 292 & 73 & 0.25 & 26.9 & 0.000382 & 1.41 & 9.332 & 0.136 & 0.0728 & 0.0014 & 0.1057 & 0.0016 & & & & & & 647.5 & 9.2 & & & \\
\hline 9.1 & 350 & 4 & 0.01 & 22.7 & 0.000117 & 0.34 & 13.261 & 0.156 & 0.0591 & 0.0008 & 0.0752 & 0.0009 & & & & & & 467.1 & 5.4 & & & \\
\hline 10.1 & 782 & 11 & 0.01 & 50.8 & 0.000064 & 0.10 & 13.229 & 0.144 & 0.0573 & 0.0006 & 0.0755 & 0.0008 & & & & & & 469.3 & 5.0 & & & \\
\hline 11.1 & 355 & 182 & 0.51 & 23.6 & 0.000135 & $<0.01$ & 12.930 & 0.178 & 0.0555 & 0.0008 & 0.0775 & 0.0011 & & & & & & 480.9 & 6.5 & & & \\
\hline 12.1 & 966 & 7 & 0.01 & 62.0 & 0.000080 & 0.01 & 13.389 & 0.145 & 0.0563 & 0.0005 & 0.0747 & 0.0008 & & & & & & 464.3 & 4.9 & & & \\
\hline 13.1 & 327 & 67 & 0.20 & 49.8 & 0.000172 & 0.29 & 5.640 & 0.066 & 0.0795 & 0.0007 & 0.1768 & 0.0021 & 1.878 & 0.034 & 0.0770 & 0.0010 & 0.653 & 1049 & 11 & 1122 & 27 & 6 \\
\hline 14.1 & 260 & 273 & 1.05 & 17.3 & 0.000310 & 0.11 & 12.936 & 0.159 & 0.0576 & 0.0009 & 0.0772 & 0.0010 & & & & & & 479.5 & 5.8 & & & \\
\hline 15.1 & 306 & 63 & 0.21 & 35.8 & 0.001067 & 1.86 & 7.330 & 0.087 & 0.0848 & 0.0008 & 0.1339 & 0.0016 & 1.284 & 0.050 & 0.0696 & 0.0026 & 0.314 & 810 & 9 & 915 & 75 & 11 \\
\hline 16.1 & 180 & 69 & 0.38 & 11.7 & 0.000261 & 0.20 & 13.138 & 0.175 & 0.0581 & 0.0012 & 0.0760 & 0.0010 & & & & & & 472.0 & 6.2 & & & \\
\hline 17.1 & 182 & 145 & 0.80 & 11.8 & 0.000478 & 0.60 & 13.246 & 0.183 & 0.0612 & 0.0012 & 0.0750 & 0.0011 & & & & & & 466.5 & 6.4 & & & \\
\hline 18.1 & 236 & 81 & 0.34 & 43.0 & 0.000077 & 0.13 & 4.712 & 0.059 & 0.0804 & 0.0007 & 0.2122 & 0.0028 & 2.351 & 0.060 & 0.0804 & 0.0013 & 0.807 & 1241 & 15 & 1206 & 33 & -3 \\
\hline 19.1 & 102 & 44 & 0.44 & 20.9 & 0.000389 & 0.64 & 4.181 & 0.062 & 0.0881 & 0.0013 & 0.2384 & 0.0038 & 2.801 & 0.122 & 0.0852 & 0.0029 & 0.704 & 1378 & 20 & 1321 & 66 & -4 \\
\hline 20.1 & 215 & 48 & 0.22 & 34.7 & 0.000178 & 0.30 & 5.323 & 0.067 & 0.0782 & 0.0008 & 0.1874 & 0.0024 & 1.967 & 0.048 & 0.0761 & 0.0013 & 0.771 & 1107 & 13 & 1098 & 33 & -1 \\
\hline 21.1 & 408 & 21 & 0.05 & 62.0 & 0.000117 & 0.20 & 5.652 & 0.077 & 0.0760 & 0.0006 & 0.1766 & 0.0024 & 1.809 & 0.032 & 0.0743 & 0.0008 & 0.775 & 1048 & 13 & 1049 & 22 & 0 \\
\hline 22.1 & 23 & 1 & 0.06 & 3.7 & 0.001988 & 3.36 & 5.291 & 0.134 & 0.0911 & 0.0026 & 0.1853 & 0.0049 & 1.902 & 0.121 & 0.0745 & 0.0039 & 0.611 & 1096 & 26 & 1054 & 105 & -4 \\
\hline 23.1 & 278 & 43 & 0.16 & 23.1 & 0.000225 & 0.82 & 10.353 & 0.201 & 0.0663 & 0.0009 & 0.0958 & 0.0019 & & & & & & 589.7 & 11.2 & & & \\
\hline 24.1 & 463 & 183 & 0.40 & 96.4 & 0.000127 & 0.21 & 4.123 & 0.048 & 0.0882 & 0.0007 & 0.2423 & 0.0030 & 2.918 & 0.067 & 0.0873 & 0.0013 & 0.836 & 1399 & 15 & 1368 & 28 & -2 \\
\hline 25.1 & 170 & 182 & 1.07 & 11.0 & 0.000521 & 0.70 & 13.217 & 0.221 & 0.0620 & 0.0012 & 0.0751 & 0.0013 & & & & & & 467.0 & 7.7 & & & \\
\hline 26.1 & 210 & 83 & 0.40 & 38.4 & 0.000125 & 0.21 & 4.689 & 0.061 & 0.0833 & 0.0009 & 0.2130 & 0.0030 & 2.412 & 0.072 & 0.0822 & 0.0017 & 0.786 & 1245 & 16 & 1249 & 40 & 0 \\
\hline
\end{tabular}

Notes:

1. Uncertainties given at the 1 os level.

2. Error in AS3 reference zircon calibration was $0.22 \%$ and $0.29 \%$ for the analytical sessions. (not included in above errors but required when comparing ${ }^{206} \mathrm{~Pb} /{ }^{238} \mathrm{U} \mathrm{data}$ from different mounts)

3. $\mathrm{f}_{206} \%$ denotes the percentage of ${ }^{206} \mathrm{~Pb}$ that is common $\mathrm{Pb}$.

4. For areas older than $\sim 800 \mathrm{Ma}$ correction for common $\mathrm{Pb}$ made using the measured ${ }^{204} \mathrm{~Pb} /{ }^{206} \mathrm{~Pb}$ ratio.

5. For areas younger than $\sim 800 \mathrm{Ma}$ correction for common $\mathrm{Pb}$ made using the measured ${ }^{238} \mathrm{U} /{ }^{206} \mathrm{~Pb}$ and ${ }^{207} \mathrm{~Pb} /{ }^{206} \mathrm{~Pb}$ ratios following Tera and Wasserburg (1972) as outlined in Williams (1998).

6. For \% Disc, $0 \%$ denotes a concordant analysis.

7. Spot numbers in italics were analysed on SHRIMP I, the remainder on SHRIMP II.

8. Data processed using SQUID (Ludwig, 2003) and Isoplot/Ex (Ludwig, 2001). 
A
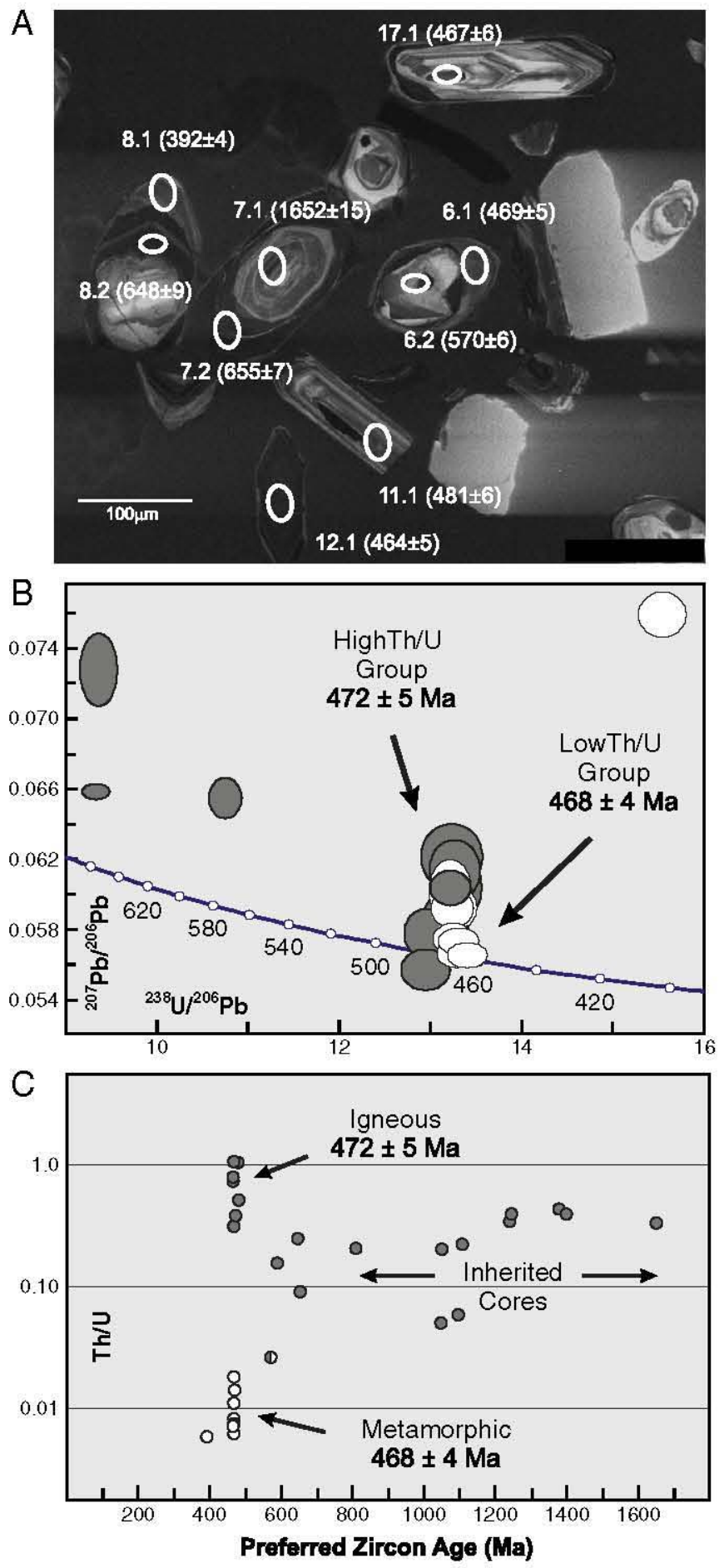

Fig. 2. U-Pb zircon results for migmatite gneiss SVF-709: A. CL image of part of the analysed mount with indentified spots and ages ( $1-\sigma$ uncertainties); B. Tera-Wasserburg plot of uncorrected data yielding ${ }^{207} \mathrm{~Pb}$-corrected ages $<700 \mathrm{Ma}$, showing overlap between igneous and metamorphic zircon at ca. $470 \mathrm{Ma}$; $\mathrm{C}$. plot of preferred zircon age vs. $\mathrm{Th} / \mathrm{U}$ as an indicator of metamorphic or igneous origin.

value is rejected, the remaining 7 have a weighted average of $468 \pm 2 \mathrm{Ma}$ (MSWD $=0.45$ ) (Fig. 2B). Thus the age of metamorphism is indistinguishable from the youngest detrital zircon ages, between them bracketing the age of the sedimentary protolith at $468 \pm 3 \mathrm{Ma}$. This signifies that sedimentation was essentially contemporaneous with the peak of Famatinian magmatism and that burial to low crustal depths and metamorphism took place soon after sedimentation. It is also implied that emplacement of the garnet amphibolite dykes took place within this same time interval. Older zircon ages are too few to precisely characterize the detrital pattern, but at least two groups are recognised: 570-655 Ma $(\mathrm{n}=4)$ and $1050-1370 \mathrm{Ma}(\mathrm{n}=8)$, with a single grain at $1650 \mathrm{Ma}$.

\section{Geochemistry}

Our database of chemical analyses of (meta-) igneous and metasedimentary rocks from the Sierra de Valle Fértil and Las Chacras consists of 84 new analyses and five from Pankhurst et al. (2000); 26 selected analyses are given in Table 3 . New Nd and $\mathrm{Sr}$ isotope data for 29 similarly representative samples are given in Table 4.

The amphibolites from Sierra de Valle Fértil and Las Chacras $(n=8)$ have silica and alumina contents in the typical range of basalt and basaltic andesite $\left(\mathrm{SiO}_{2}=48-54 \% ; \mathrm{Al}_{2} \mathrm{O}_{3}=12.0-15.5 \%\right)$. They are subalkaline $\left(\mathrm{Na}_{2} \mathrm{O}+\mathrm{K}_{2} \mathrm{O}=1.7-3.8 \%\right)$ with variable molar $\mathrm{Mg}$-number (45-72). They have flat REE patterns $\left(\mathrm{La} / \mathrm{Yb}_{\mathrm{cn}}=1-3\right)$ and little or no negative Eu anomalies $\left(\mathrm{Eu} / \mathrm{Eu}^{*}=1.0-0.8\right)$, suggesting weak feldspar fractionation. Relative to N-MORB (Fig. 3A), they show enrichment of large ion lithophile elements ( $\mathrm{Cs}, \mathrm{Rb}, \mathrm{Ba}, \mathrm{K}), \mathrm{Ba} / \mathrm{La}=16-37$ and $\mathrm{Nb}$ depletion, all of which are characteristic features of primitive subduction-related basic rocks.

The amphibolite compositions can be distinguished from those of the voluminous igneous rocks of the VFPS, which show a marked silica gap at $59-63 \% \mathrm{SiO}_{2}$ (Fig. 3B and D). Although there is overlap with the gabbros and diorites of the VFPS in terms of silica and trace elements, many of the gabbros are opx $-\mathrm{cpx} \pm$ ol varieties, with lower silica $\left(\mathrm{SiO}_{2}=40-47 \%\right)$ and higher alumina $\left(\mathrm{Al}_{2} \mathrm{O}_{3}=15.4-26.5 \%\right)$, indicating their essentially cumulate nature, as suggested by Otamendi et al. (2009). However, the Las Chacras amphibolites have a depleted-source Nd isotopic signature: three samples have positive $\varepsilon \mathrm{Nd}_{t}$ ranging from +1.8 to +4.8 , with one at -0.1 which is very close to the chondritic reservoir value. These values contrast sharply with the more evolved character of the VFPS (negative $\varepsilon \mathrm{Nd}_{\mathrm{t}}$ of -1.9 to -5.5 ; Table 4 ), although it should be noted that Otamendi et al. (2012) reported a value of +0.9 for a single sample of two-pyroxene gabbro. MORB sources have present-day ${ }^{143} \mathrm{Nd} /{ }^{144} \mathrm{Nd}$ ratios in the range $0.5130-0.5132$; assuming a mean ${ }^{147} \mathrm{Sm} /{ }^{144} \mathrm{Nd}$ ratio of 0.222 , the $\varepsilon N d t$ values of an Ordovician MORB-type mantle source would have been in the range +5.5 to +9.5 (Fig. 3D). Thus even the most radiogenic amphibolite, with an $\varepsilon N d t$ of +4.7 cannot have been derived directly from a MORB-type source. The Nd isotopic compositions of the amphibolites therefore reflect either a degree of crustal contamination (albeit much less than shown by the VFPS), or they were derived from a less depleted source. Present-day $\varepsilon N d$ values for modern primitive arc basalts based on the average compositions given by Kelemen et al. (2005) for oceanic and continental varieties are approximately +6.7 and +5.5 respectively; the equivalent Ordovician mantle sources, assuming continuous isotopic evolution following mantle fractionation at about $2800 \mathrm{Ma}$, would be roughly +5.5 and +4.5 (see Fig. 3D). Initial ${ }^{87} \mathrm{Sr} /{ }^{86} \mathrm{Sr}$ ratios of the amphibolites $(0.7054-0.7080)$ are mostly lower than in the gabbros and diorites of the VFPS $(0.7072-0.7113$, discounting unreliable values for two samples with high $\mathrm{Rb} / \mathrm{Sr}$ ratios), but higher than in recent arc-related basalts (Kelemen et al., 2005) (Fig. 3C), and clearly indicate contamination with radiogenic $\mathrm{Sr}$, probably due to the mobility of Sr during the high-grade metamorphism that affected the basaltic protoliths. We assume that the igneous protoliths of the amphibolites would have plotted farther to the left in Fig. 3C, i.e., entirely within the depleted mantle field. The $\mathrm{\varepsilon Nd}_{\mathrm{t}}$ and initial ${ }^{87} \mathrm{Sr} /{ }^{86} \mathrm{Sr}$ values for basic and acid rocks of the VFPS are essentially invariant, with $\mathrm{Nd}$ model ages (TDM*, after DePaolo et al., 1991) ranging from 1.3 to $1.5 \mathrm{Ga}$ compared to $<1.2 \mathrm{Ga}$ for the amphibolites (see Table 4). The isotopic signatures of the paragneisses and migmatites are rather more evolved still $\left(\varepsilon N d_{t}=-4.6\right.$ to -7.1 , initial ${ }^{87} \mathrm{Sr} /{ }^{86} \mathrm{Sr}=0.717$ to 0.730$)$, although in terms of major element composition they fall between the basic and 
Table 3

Selected chemical analyses of igneous and metamorphic rocks from Sierra de Valle Fértil.

\begin{tabular}{|c|c|c|c|c|c|c|c|c|c|c|c|c|c|c|}
\hline \multicolumn{15}{|c|}{ Metamorphic rocks } \\
\hline \multicolumn{7}{|c|}{ Amphibolites } & \multicolumn{8}{|c|}{ High-grade paragneisses and migmatites } \\
\hline Sample & SVF202 & SVF 715 & SVF716 & SVF609 & SVF704 & SVF201 & SVF581 & SVF709 & SVF513 & SVF611 & SVF608 & SVF551 & SVF579 & SVF515 \\
\hline Locality $^{\text {a }}$ & SVF & LLC & LLC & SVF & LLC & LLC & SVF & LLC & SVF & SVF & SVF & SVF & SVF & SVF \\
\hline \multicolumn{15}{|c|}{ Major oxides (wt\%) } \\
\hline $\mathrm{SiO} 2$ & 47.81 & 49.05 & 51.36 & 51.79 & 52.09 & 52.14 & 52.52 & 56.20 & 57.73 & 60.25 & 61.60 & 62.78 & 69.13 & 72.35 \\
\hline $\mathrm{TiO} 2$ & 0.73 & 1.23 & 1.45 & 0.83 & 1.18 & 0.89 & 1.52 & 1.19 & 1.20 & 1.17 & 1.02 & 1.37 & 0.76 & 0.70 \\
\hline $\mathrm{Al} 203$ & 11.98 & 14.90 & 13.35 & 15.54 & 13.55 & 14.88 & 20.96 & 19.41 & 17.04 & 18.05 & 17.23 & 13.27 & 12.95 & 12.72 \\
\hline $\mathrm{Fe} 2 \mathrm{O} 3$ & 3.57 & 0.99 & 0.36 & 3.04 & 2.70 & 4.21 & 5.33 & 4.16 & 2.69 & 1.82 & 3.27 & 3.48 & 1.74 & 3.64 \\
\hline $\mathrm{FeO}$ & 7.28 & 10.33 & 12.82 & 6.41 & 9.08 & 5.83 & 7.62 & 6.00 & 6.63 & 5.93 & 4.76 & 5.27 & 4.14 & 3.06 \\
\hline MnO & 0.18 & 0.19 & 0.22 & 0.18 & 0.19 & 0.19 & 0.26 & 0.22 & 0.14 & 0.20 & 0.18 & 0.06 & 0.11 & 0.13 \\
\hline $\mathrm{MgO}$ & 14.90 & 6.29 & 6.28 & 7.66 & 5.29 & 7.45 & 5.65 & 4.06 & 3.71 & 3.78 & 3.32 & 3.06 & 2.39 & 2.64 \\
\hline $\mathrm{CaO}$ & 9.58 & 10.07 & 10.51 & 11.13 & 8.75 & 10.59 & 1.30 & 0.81 & 2.67 & 1.02 & 1.07 & 2.81 & 1.49 & 1.63 \\
\hline $\mathrm{Na} 2 \mathrm{O}$ & 1.03 & 2.85 & 1.87 & 1.21 & 2.71 & 1.28 & 1.58 & 1.60 & 1.87 & 1.71 & 1.74 & 2.02 & 1.77 & 1.67 \\
\hline $\mathrm{K} 2 \mathrm{O}$ & 0.73 & 0.25 & 0.25 & 0.54 & 0.64 & 0.45 & 1.93 & 4.80 & 2.38 & 2.65 & 4.26 & 3.01 & 2.31 & 1.17 \\
\hline P2O5 & 0.07 & 0.12 & 0.13 & 0.09 & 0.12 & 0.10 & 0.03 & 0.09 & 0.12 & 0.12 & 0.06 & 0.03 & 0.08 & 0.04 \\
\hline $\mathrm{H} 2 \mathrm{O}+$ & 1.25 & 0.32 & 0.07 & 0.79 & 0.47 & 1.27 & 0.87 & 1.53 & 0.79 & 0.70 & 1.10 & 0.99 & 0.81 & 0.56 \\
\hline $\mathrm{H} 2 \mathrm{O}-$ & 0.13 & 0.38 & 0.30 & 0.10 & 0.05 & 0.13 & 0.15 & 0.23 & 0.20 & 0.18 & 0.21 & 0.13 & 0.10 & 0.15 \\
\hline Total & 99.24 & 96.97 & 98.97 & 99.31 & 96.82 & 99.41 & 99.72 & 100.30 & 97.17 & 97.58 & 99.82 & 98.28 & 97.78 & 100.46 \\
\hline Molar Mg\# & 71.70 & 49.99 & 46.00 & 59.90 & 45.04 & 58.01 & 44.80 & 42.62 & 42.23 & 47.11 & 43.46 & 39.37 & 42.76 & 42.63 \\
\hline \multicolumn{15}{|c|}{ Trace elements (ppm) } \\
\hline Cs & 0.5 & 0.7 & 0.2 & 0.9 & 0.2 & 0.5 & 1.1 & 5.8 & 1.8 & 2.5 & 0.7 & 0.6 & 1.0 & 0.5 \\
\hline $\mathrm{Rb}$ & 15.0 & 4.0 & 6.0 & 4.0 & 12.0 & 13.0 & 75.0 & 213.0 & 103.0 & 95.0 & 84.0 & 99.0 & 64.0 & 37.0 \\
\hline $\mathrm{Sr}$ & 109 & 241 & 124 & 103 & 149 & 193 & 106 & 104 & 157 & 167 & 155 & 179 & 142 & 136 \\
\hline $\mathrm{Ba}$ & 530 & 115 & 134 & 91 & 183 & 130 & 490 & 534 & 363 & 660 & 1200 & 1040 & 555 & 350 \\
\hline La & 4.5 & 7.1 & 5.6 & 4.8 & 9.5 & 7.7 & 66.9 & 60.5 & 63.7 & 66.7 & 58.9 & 40.6 & 55.9 & 63.7 \\
\hline $\mathrm{Ce}$ & 12 & 21 & 16 & 14 & 29 & 19 & 131 & 132 & 132 & 140 & 124 & 72 & 114 & 127 \\
\hline Nd & 6 & 12 & 11 & 8 & 16 & 9 & 52 & 56 & 58 & 57 & 51 & 26 & 52 & 54 \\
\hline $\mathrm{Sm}$ & 1.90 & 3.06 & 3.03 & 2.10 & 3.51 & 2.80 & 8.41 & 8.75 & 11.20 & 9.98 & 7.96 & 3.13 & 9.11 & 8.60 \\
\hline Eu & 0.70 & 1.10 & 1.17 & 0.76 & 1.14 & 0.80 & 1.53 & 1.94 & 1.96 & 2.09 & 1.52 & 1.35 & 1.74 & 1.43 \\
\hline $\mathrm{Tb}$ & 0.5 & 0.7 & 0.8 & 0.5 & 0.9 & 0.6 & 0.8 & 1.3 & 1.6 & 1.4 & 1.0 & 0.2 & 1.2 & 0.7 \\
\hline $\mathrm{Yb}$ & 1.7 & 3.1 & 3.4 & 2.0 & 3.4 & 2.6 & 1.6 & 4.1 & 4.3 & 3.5 & 1.3 & 0.8 & 2.6 & 1.4 \\
\hline $\mathrm{Lu}$ & 0.3 & 0.4 & 0.5 & 0.3 & 0.5 & 0.4 & 0.3 & 0.6 & 0.7 & 0.5 & 0.2 & 0.2 & 0.4 & 0.2 \\
\hline $\mathrm{U}$ & 0.5 & 0.9 & 0.3 & 0.1 & 0.4 & 1.0 & 0.8 & 1.4 & 0.1 & 2.1 & 0.9 & 0.5 & 1.0 & 0.7 \\
\hline Th & 0.6 & 1.8 & 1.0 & 0.9 & 2.9 & 1.5 & 18.6 & 21.0 & 19.3 & 20.7 & 22.0 & 6.9 & 17.9 & 18.7 \\
\hline $\mathrm{Y}$ & 22 & 29 & 33 & 21 & 31 & 29 & 19 & 40 & 39 & 32 & 23 & 9 & 28 & 18 \\
\hline $\mathrm{Nb}$ & 2 & 5 & 4 & 3 & 5 & 3 & 14 & 22 & 15 & 18 & 14 & 16 & 6 & 6 \\
\hline $\mathrm{Zr}$ & 67 & 98 & 91 & 64 & 112 & 90 & 299 & 231 & 274 & 264 & 226 & 437 & 334 & 428 \\
\hline Hf & 1.4 & 2.7 & 2.8 & 1.9 & 3.3 & 2.2 & 7.6 & 6.2 & 8.0 & 7.1 & 5.0 & 12.1 & 9.1 & 10.8 \\
\hline $\mathrm{Sc}$ & 34 & 46 & 43 & 41 & 42 & 40 & 24 & 24 & 35 & 23 & 13 & 14 & 13 & 10 \\
\hline $\mathrm{Ga}$ & 10 & 17 & 19 & 15 & 16 & 14 & 33 & 32 & 20 & 23 & 18 & 20 & 14 & 10 \\
\hline $\mathrm{Co}$ & 67 & 56 & 62 & 51 & 53 & 40 & 35 & 43 & 34 & 28 & 19 & 41 & 17 & 14 \\
\hline $\mathrm{Cr}$ & 1000 & 9 & 116 & 346 & 25 & 310 & 144 & 109 & 187 & 146 & 103 & 146 & 103 & 141 \\
\hline
\end{tabular}

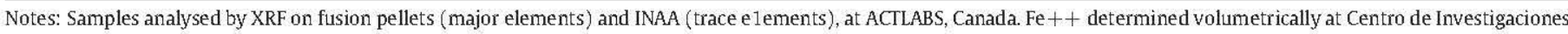
Geológicas, La Plata.

${ }^{a}$ SVF $=$ Sierra de Valle Fertil, LLC $=$ Loma de Las Chacras.

(continued on next page)

the acid components of the VFPS (Fig. 3D); their TDM* model ages are 1.6 to $1.7 \mathrm{Ga}$.

\section{Discussion and conclusions}

Evidence from U-Pb SHRIMP detrital zircon dating of high-grade gneisses from Las Chacras suggests that the sedimentary protoliths were deposited essentially coevally with Famatinian magmatism at ca. $468 \pm 3 \mathrm{Ma}$ and that they were buried and metamorphosed at high pressure (ca. $1.2 \mathrm{GPa}$ ) and high temperature $\left(\mathrm{ca} .780^{\circ} \mathrm{C}\right.$ ) soon after sedimentation. The structural position of the Las Chacras highgrade core relative to the Valle Fértil igneous-metamorphic belt suggests that burial took place outboard of the magmatic arc and that these metasediments underplated the arc. No eclogite or blue-schist facies rocks have been recognised. A medium T/P gradient metamorphism at Las Chacras contrasts with the low T/P conditions typical of subduction zones, suggesting that heat from the nearby hot lower crust of the magmatic arc may have played a role during underthrusting. Subduction of the Las Chacras sediments was comparatively slow to allow for thermal relaxation at depth. In fact, the P-T evolution inferred from garnet zoning in kyanite-garnet gneisses suggests that significant heating took place during subduction, at the same time as ductile thrust-related foliation developed. On the other hand, preservation of garnet zoning in spite of the high temperatures attained implies that rocks were exhumed after subduction on a time-scale less than typical for Barrovian regional metamorphism, i.e., probably less than $10 \mathrm{Ma}$. In fact, garnet homogenization takes place at temperatures over $650^{\circ} \mathrm{C}$ (Tracy, 1982) over a time period of ca. 12-18 Ma which is now thought to be the duration of classical Barrovian metamorphism in the Grampians (Viete et al., 2011, and references therein).

Cases of magmatic arc underplating by forearc sediments along a relatively high T/P geotherm have been recorded from other palaeo-active margins. Such is the case of the Swakane gneiss in the North Cascades metamorphic core (Matzel and Bowring, 2004). The sedimentary protolith to the gneiss was deposited in a forearc or back-arc basin in the Late Cretaceous and deeply buried to depths equivalent to $0.9-1.2 \mathrm{GPa}$ at temperatures of $640-740^{\circ} \mathrm{C}$, i.e., Barrovian conditions, within $5 \mathrm{Ma}$ of deposition. Ducea et al. (2009) recognised a similar case represented by the Salinas Schist of the Monterey terrane in Central California. The Salinas Schist was deposited, deeply buried to depths equivalent to ca. $1.0 \mathrm{GPa}$ and partially melted quickly, between 79 and $68 \mathrm{Ma}$. According to Ducea et al. (2009) subduction of the Salinas Schist, allegedly 


\begin{tabular}{|c|c|c|c|c|c|c|c|c|c|c|c|}
\hline \multicolumn{12}{|c|}{ Sierra de Valle Fertil plutonic suite } \\
\hline \multicolumn{6}{|c|}{ Gabbros and diorites } & \multicolumn{6}{|c|}{ Granitic rocks } \\
\hline SVF500 & SVF501 & SVF605 & SVF502 & SVF584 & SVF571 & SVF508 & SVF532 & SVF521 & SVF540 & SVF564 & SVF603 \\
\hline SVF & SVF & SVF & SVF & SVF & SVF & SVF & SVF & SVF & SVF & SVF & SVF \\
\hline 40.32 & 41.76 & 42.66 & 45.52 & 48.50 & 49.10 & 64.35 & 64.73 & 64.76 & 67.17 & 72.15 & 76.07 \\
\hline 0.06 & 1.43 & 0.04 & 0.48 & 0.22 & 1.17 & 0.74 & 0.59 & 0.68 & 0.47 & 0.06 & 0.04 \\
\hline 16.53 & 18.26 & 24.84 & 17.50 & 18.32 & 20.42 & 15.82 & 14.89 & 14.84 & 14.72 & 13.81 & 13.16 \\
\hline 2.32 & 5.46 & 0.87 & 2.30 & 0.57 & 1.92 & 2.27 & 2.04 & 1.36 & 1.66 & 0.27 & 0.02 \\
\hline 7.93 & 10.45 & 4.34 & 9.51 & 7.17 & 7.23 & 4.25 & 3.51 & 4.19 & 2.45 & 0.94 & 0.73 \\
\hline 0.15 & 0.24 & 0.09 & 0.21 & 0.16 & 0.18 & 0.11 & 0.11 & 0.12 & 0.12 & 0.12 & 0.11 \\
\hline 19.92 & 7.39 & 10.45 & 12.73 & 10.90 & 4.77 & 2.19 & 1.68 & 1.84 & 1.24 & 0.17 & 0.09 \\
\hline 8.86 & 12.85 & 13.55 & 9.90 & 11.96 & 8.03 & 5.28 & 4.46 & 4.72 & 3.78 & 0.85 & 0.80 \\
\hline 0.33 & 0.80 & 0.64 & 0.74 & 0.68 & 3.06 & 2.73 & 2.89 & 2.76 & 3.30 & 3.45 & 3.90 \\
\hline 0.03 & 0.04 & 0.08 & 0.47 & 0.11 & 0.40 & 1.71 & 2.65 & 2.57 & 3.14 & 4.96 & 4.80 \\
\hline 0.02 & 0.02 & 0.08 & 0.04 & 0.02 & 0.04 & 0.16 & 0.23 & 0.16 & 0.13 & 0.06 & 0.02 \\
\hline 3.16 & 0.43 & 1.55 & 0.20 & 0.49 & 0.65 & 0.40 & 0.81 & 0.57 & 0.23 & 0.39 & 0.31 \\
\hline 0.12 & 0.05 & 0.21 & 0.27 & 0.15 & 0.25 & 0.15 & 0.13 & 0.07 & 0.30 & 0.25 & 0.10 \\
\hline 99.75 & 99.18 & 99.40 & 99.87 & 99.25 & 97.22 & 100.16 & 98.72 & 98.64 & 98.71 & 97.48 & 100.15 \\
\hline 78.02 & 46.17 & 78.46 & 66.23 & 71.68 & 48.71 & 38.29 & 35.91 & 37.73 & 35.92 & 20.39 & 17.66 \\
\hline 0.3 & 0.2 & 0.2 & 0.2 & 0.2 & 0.2 & 1.0 & 2.1 & 1.2 & 2.3 & 6.1 & 0.2 \\
\hline 0.5 & 0.2 & 0.1 & 11.8 & 2.1 & 8.5 & 59.0 & 97.0 & 99.0 & 124.0 & 245.0 & 148.0 \\
\hline 99 & 168 & 171 & 144 & 157 & 256 & 174 & 157 & 160 & 137 & 37 & 40 \\
\hline 20 & 20 & 20 & 70 & 40 & 96 & 400 & 572 & 480 & 500 & 230 & 216 \\
\hline 0.9 & 1.2 & 0.6 & 3.2 & 1.9 & 30.6 & 32.5 & 33.8 & 33.9 & 28.9 & 14.4 & 19.5 \\
\hline 2 & 4 & 2 & 8 & 4 & 54 & 60 & 71 & 70 & 58 & 34 & 40 \\
\hline 1 & 4 & 1 & 5 & 3 & 17 & 22 & 27 & 29 & 25 & 15 & 14 \\
\hline 0.18 & 1.18 & 0.12 & 1.31 & 0.67 & 1.95 & 3.58 & 5.40 & 5.31 & 5.36 & 3.18 & 2.52 \\
\hline 0.12 & 0.43 & 0.10 & 0.41 & 0.27 & 1.28 & 1.18 & 1.12 & 1.13 & 1.04 & 0.40 & 0.76 \\
\hline 0.1 & 0.3 & 0.1 & 0.3 & 0.2 & 0.4 & 0.4 & 0.8 & 0.9 & 0.9 & 0.6 & 0.8 \\
\hline 0.2 & 1.0 & 0.1 & 0.9 & 0.6 & 1.0 & 1.3 & 2.6 & 2.6 & 3.8 & 3.6 & 5.4 \\
\hline 0.0 & 0.2 & 0.0 & 0.1 & 0.1 & 0.2 & 0.2 & 0.4 & 0.4 & 0.6 & 0.5 & 0.7 \\
\hline 0.1 & 0.1 & 0.1 & 0.1 & 0.1 & 0.1 & 0.4 & 0.9 & 0.5 & 1.1 & 1.4 & 0.4 \\
\hline 0.1 & 0.1 & 0.2 & 0.3 & 0.1 & 3.7 & 2.6 & 11.7 & 10.3 & 11.3 & 8.3 & 1.9 \\
\hline 2 & 14 & 2 & 10 & 3 & 5 & 13 & 31 & 36 & 43 & 37 & 38 \\
\hline 2 & 2 & 2 & 2 & 2 & 6 & 8 & 8 & 14 & 13 & 21 & 2 \\
\hline 20 & 26 & 16 & 33 & 26 & 132 & 208 & 193 & 221 & 165 & 72 & 52 \\
\hline 0.2 & 0.2 & 0.2 & 0.5 & 0.2 & 3.4 & 6.1 & 4.7 & 4.6 & 3.9 & 2.1 & 2 \\
\hline 8 & 52 & 5 & 21 & 37 & 32 & 16 & 17 & 21 & 14 & 5 & 5 \\
\hline 5 & 14 & 6 & 8 & 9 & 22 & 11 & 11 & 13 & 11 & 14 & 11 \\
\hline 112 & 43 & 50 & 65 & 46 & 31 & 18 & 12 & 13 & 8 & 1 & 1 \\
\hline 173 & 51 & 273 & 31 & 294 & 35 & 96 & 68 & 46 & 47 & 51 & 51 \\
\hline
\end{tabular}

deposited at an accretionary wedge, led to underplating of the crustal section of the magmatic arc exposed in the juxtaposed Salinian block of the Monterey terrane following a hotter than typical subduction path.

The canonical interpretation of the Early to Mid-Ordovician evolution of this segment of the Famatinian belt involves the approach and collision with the Gondwana margin, of a Laurentia-derived exotic terrane, i.e., the Precordillera terrane - or the Cuyania composite terrane (Ramos et al., 1986; Astini et al., 1995; Thomas and Astini, 2003) (for a review of the Cuyania composite terrane see Ramos, 2004). The Precordillera terrane consists of an Early Cambrian to early MidOrdovician carbonate platform (the Argentine Precordillera) and a late-Mesoproterozoic, i.e., Grenvillian s.l, and Neoproterozoic basement that crops out in the Sierra de Pie de Palo and elsewhere (Casquet et al., 2001) (Fig. 1). In this interpretation, the eastern boundary of the Precordillera terrane lies between the Sierra de Pie de Palo and the Sierra de Valle Fértil (Fig. 1) and accordingly the Las Chacras high-grade metamorphic core could correspond to a subducted frontal accretionary wedge as suggested by Thomas and Astini (2003). Collision of the Precordillera/Cuyania terrane with the Gondwana margin was dated at ca. $460 \mathrm{Ma}$ by Casquet et al. (2001) on geochronological evidence from metamorphism in a Famatinian ductile thrust zone in the Sierra de Pie de Palo.
As an alternative view, the Las Chacras metasedimentary rocks may have been laid down in a forearc basin far from the leading edge of the overriding plate. This interpretation is supported by the following: higher pressure and lower temperature values than those of the Las Chacras gneisses have been reported for the Famatinian metamorphism in the Sierra de Pie de Palo (Casquet et al., 2001; Mulcahy et al., 2011). Blueschist facies conditions have even been recorded from near the Pirquitas thrust zone on the western slope of the Sierra de Pie de Palo (Fig. 1) (Vujovich, 2011) suggesting that the main subduction zone laid to the west. Accordingly a forearc basement probably existed between the Las Chacras basin and the continental edge, probably represented by the structurally higher part of the Sierra de Pie de Palo (Casquet et al., 2001). The latter was buried to depths greater than the Las Chacras gneisses in the overriding plate during Alpine-style collision (van Staal et al., 2011) and later exhumed (Mulcahy et al, 2011). Moreover, subductionrelated magmatism represented by the Las Chacras amphibolites suggests that the mantle wedge source of the parent magmas laid beneath the sedimentary basin, as is typical of subduction zone magmatism triggered by fluids derived from the subducting slab at depths of ca. $90 \mathrm{~km}$ under the arc (e.g., Zhao, 2001), implying that the basin was on the upper plate. 
$\mathrm{Sm}-\mathrm{Nd}$ and $\mathrm{Rb}-\mathrm{Sr}$ isotope data for Sierra de Valle Fértil samples.

\begin{tabular}{|c|c|c|c|c|c|c|c|c|c|c|c|c|c|c|}
\hline Sample & Rock type & Age Ma & $\mathrm{Sm}$ & Nd & ${ }^{147} \mathrm{Sm} /{ }^{144} \mathrm{Nd}$ & ${ }^{143} \mathrm{Nd} /{ }^{144} \mathrm{Nd}$ & ${ }^{143} \mathrm{Nd} /{ }^{144} \mathrm{Ndt}$ & $\varepsilon \mathrm{Ndt}$ & $\mathrm{TDM}^{*}$ & $\mathrm{Rb}$ & $\mathrm{Sr}$ & ${ }^{87} \mathrm{Rb} /{ }^{86} \mathrm{Sr}$ & ${ }^{87} \mathrm{Sr} /{ }^{86} \mathrm{Sr}$ & ${ }^{87} \mathrm{Sr} /{ }^{86} \mathrm{Srt}$ \\
\hline \multicolumn{15}{|c|}{ Loma de Las Chacras } \\
\hline SVF7 15 & Gt-amphibolite & 470 & 3.371 & 11.710 & 0.1741 & 0.512662 & 0.512126 & 1.8 & 1042 & 4.4 & 240.6 & 0.053 & 0.708363 & 0.7080 \\
\hline SVF7 16 & Gt-amphibolite & 470 & 3.432 & 10.926 & 0.1899 & 0.512861 & 0.512276 & 4.8 & 772 & 5.9 & 124.4 & 0.138 & 0.706296 & 0.7054 \\
\hline SVF609 & Amphibolite & 470 & 2.227 & 7.405 & 0.1818 & 0.512745 & 0.512185 & 3.0 & 939 & 4.0 & 103.2 & 0.112 & 0.706910 & 0.7062 \\
\hline SVF704 & Amphibolite & 470 & 3.836 & 14.808 & 0.1566 & 0.512509 & 0.512027 & -0.1 & 1206 & 12.4 & 149.2 & 0.241 & 0.709348 & 0.7077 \\
\hline SVF709 & Migmatite & 469 & 9.979 & 52.229 & 0.1155 & 0.512036 & 0.511681 & -6.9 & 1722 & 212.9 & 103.9 & 5.952 & 0.751535 & 0.7118 \\
\hline \multicolumn{15}{|c|}{ Sierra de Valle Fertil } \\
\hline SVF200 & Gneiss & 520 & 9.161 & 46.954 & 0.1179 & 0.512035 & 0.511633 & -6.5 & 1733 & 80.8 & 108.0 & 2.192 & 0.729749 & 0.7135 \\
\hline SVF581 & Cordierite gneiss & 470 & 9.715 & 57.667 & 0.1018 & 0.512004 & 0.511691 & -6.7 & 1708 & 75.0 & 106.0 & 2.052 & 0.731237 & 0.7175 \\
\hline SVF513 & Garnet gneiss & 470 & 10.364 & 53.614 & 0.1168 & 0.512155 & 0.511795 & -4.6 & 1560 & 102.8 & 156.6 & 1.902 & 0.727495 & 0.7148 \\
\hline SVF611 & Migmatite & 470 & 10.057 & 53.365 & 0.1139 & 0.512018 & 0.511667 & -7.1 & 1740 & 95.1 & 167.2 & 1.650 & 0.727022 & 0.7160 \\
\hline SVF551 & Bt gneiss & 470 & 3.472 & 25.092 & 0.0836 & 0.511987 & 0.511729 & -5.9 & 1654 & 99.3 & 178.8 & 1.609 & 0.722263 & 0.7115 \\
\hline SVF579 & Cordierite gneiss & 470 & 8.909 & 46.499 & 0.1158 & 0.512042 & 0.511685 & -6.8 & 1715 & 64.3 & 142.1 & 1.311 & 0.724197 & 0.7154 \\
\hline SVF515 & Cordierite gneiss & 470 & 10.522 & 61.717 & 0.1031 & 0.512033 & 0.511716 & -6.2 & 1673 & 37.2 & 136.2 & 0.791 & 0.716497 & 0.7112 \\
\hline SVF3131 & Gt-migmatite & 472 & 5.051 & 28.735 & 0.1063 & 0.512021 & 0.511692 & -6.6 & 1704 & 64.6 & 165.9 & 1.128 & 0.720818 & 0.7132 \\
\hline \multicolumn{15}{|c|}{ SVF plutonic suite } \\
\hline SVF500 & Gabbronorite & 470 & 0.145 & 0.591 & 0.1484 & 0.512390 & 0.511933 & -1.9 & 1354 & 0.5 & 99.0 & 0.016 & 0.709066 & 0.7090 \\
\hline SVF501 & Hnb gabbro & 470 & 1.714 & 4.692 & 0.2209 & 0.512518 & 0.511838 & -3.8 & 1498 & 0.2 & 168.0 & 0.003 & 0.709391 & 0.7094 \\
\hline SVF5774 & Gabbronorite & 470 & 10.116 & 38.666 & 0.1582 & 0.512236 & 0.511749 & -5.5 & 1626 & 4.2 & 195.3 & 0.063 & 0.709467 & 0.7090 \\
\hline SVF605 & Coronitic gabbro & 470 & 0.128 & 0.548 & 0.1414 & 0.512227 & 0.511792 & -4.7 & 1565 & 0.1 & 170.8 & 0.002 & 0.709041 & 0.7090 \\
\hline SVF502 & Gabbro & 470 & 1.706 & 6.302 & 0.1636 & 0.512296 & 0.511792 & -4.7 & 1564 & 11.8 & 144.4 & 0.237 & 0.711006 & 0.7094 \\
\hline SVF3017† & Hnb gabbro & 470 & 1.771 & 6.973 & 0.1536 & 0.512332 & 0.511859 & -3.4 & 1466 & 3.0 & 231.0 & 0.038 & 0.707483 & 0.7072 \\
\hline SVF584 & Gabbronorite & 470 & 0.734 & 2.699 & 0.1644 & 0.512360 & 0.511854 & -3.5 & 1475 & 2.1 & 156.8 & 0.038 & 0.708475 & 0.7082 \\
\hline SVF571 & Gabbro & 470 & 1.922 & 17.469 & 0.0665 & 0.511959 & 0.511754 & -5.4 & 1619 & 8.5 & 255.5 & 0.097 & 0.711976 & 0.7113 \\
\hline SVF591† & Hb gabbro & 470 & 2.574 & 10.869 & 0.1432 & 0.512352 & 0.511911 & -2.4 & 1388 & 29.4 & 197.5 & 0.431 & 0.709494 & 0.7066 \\
\hline SVF508 & Tonalite & 473 & 3.339 & 20.307 & 0.0994 & 0.512084 & 0.511776 & -4.9 & 1584 & 58.8 & 174.4 & 0.977 & 0.717246 & 0.7107 \\
\hline SVF532 & Granodiorite & 470 & 5.313 & 25.695 & 0.1250 & 0.512213 & 0.511828 & -4.0 & 1512 & 96.7 & 156.5 & 1.789 & 0.721020 & 0.7090 \\
\hline SVF521 & Tonalite & 470 & 6.649 & 36.155 & 0.1112 & 0.512150 & 0.511808 & -4.4 & 1542 & 98.7 & 160.6 & 1.781 & 0.721016 & 0.7091 \\
\hline SVF540 & Granite & 470 & 5.921 & 27.486 & 0.1302 & 0.512228 & 0.511827 & -4.0 & 1514 & 124.2 & 137.4 & 2.620 & 0.726339 & 0.7088 \\
\hline SVF593† & Granodiorite & 470 & 5.261 & 23.520 & 0.1352 & 0.512217 & 0.511801 & -4.5 & 1552 & 110.5 & 122.6 & 2.613 & 0.727897 & 0.7104 \\
\hline SVF564 & Leucogranite & 470 & 4.062 & 15.714 & 0.1563 & 0.512253 & 0.511772 & -5.1 & 1594 & 244.9 & 37.3 & 19.226 & 0.833218 & 0.7045 \\
\hline SVF603 & Pink granite & 470 & 2.468 & 11.998 & 0.1243 & 0.512192 & 0.511809 & -4.4 & 1540 & 148.3 & 40.4 & 10.701 & 0.780507 & 0.7089 \\
\hline
\end{tabular}

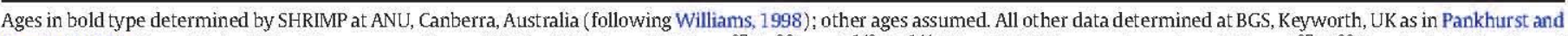

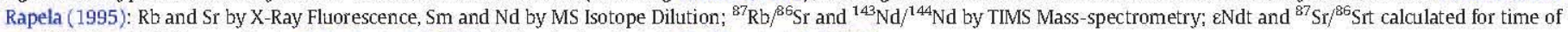
crystallization; TDM* according to DePaolo et al. (1991); † Chemical analysis in Pankhurst et al. (2000).

Inferring sources from the zircon inheritance of SVF-709 is hindered by the small number of grains available, which may be not fully representative. However, the partial detrital zircon age pattem (Fig. 2C) shows similarities with those of the Sierra de Valle Fértil migmatites that host the VFPS (Casquet et al., 2011; Cristofolini et al., 2012). The migmatite protoliths were laid down in the Middle to Late Cambrian before the onset of the Famatinian orogeny and contain a population of Early Cambrian, Neoproterozoic and Mesoproterozoic zircon grains. This evidence, along with the presence in SVF-709 of a population of detrital igneous zircons derived from Famatinian igneous rocks, suggests that provenance of zircon grains to the forearc basin was from the east, i.e., from the erosion of the VFPS and its host Middle to Late Cambrian sedimentary rocks. Remarkably, however, zircons with early Cambrian "Pampean" ages between 530 and 510 Ma that constitute the main population in metasedimentary rocks of the SVF (Cristofolini et al., 2012) are not so far recorded in SVF-709.

Burial of forearc basins under the magmatic arc has been reported from collisional zones, such as the Taiwan orogen (Malavieille and Trullenque, 2009) or the Banda arc-NW Australia collision orogen (Standley and Harris, 2009). In the latter case metamorphism of the buried forearc sequences (Banda forearc) attained amphibolite facies conditions of up to $1.0 \mathrm{GPa}$ and $680^{\circ} \mathrm{C}$ (Standley and Harris, 2009), much in line with those found at Las Chacras.

The magmas from which the garnet amphibolites were ultimately derived must have been injected at some moment during burial in the sedimentary basin or during subsequent underthrusting. They were arc-related basalts and basaltic andesites with juvenile isotopic characteristics, variable but mostly low $\mathrm{Cr}(8.7-1000 \mathrm{ppm})$ and $\mathrm{MgO}$ (5.3-14.9\%) contents and $\mathrm{Mg}$-number (45-72), as well as a weak negative Eu anomaly in three samples (Fig. 3A), the latter suggesting some early fractionation before intrusion. Their juvenile signature is very unusual for basic rocks associated with Famatinian magmatism, which generally show more evolved $\mathrm{Nd}$ and $\mathrm{Sr}$ isotopic characteristics (Pankhurst et al., 1998, 2000), and we conclude that juvenile material was thus injected into buried sediments outboard of the magmatic arc.

There is no conclusive evidence however for the processes that led to generation and diversification of the VFPS magmas. Conventionally, these magmas may have been generated from a (lithospheric) enriched mantle source different from that of the amphibolites. However the possibility that they resulted from contamination of juvenile magmas in the lower crust of the arc by granitic melts derived from host metamorphic rocks (Otamendi et al., 2009; Ducea et al., 2010; Otamendi et al., 2012) is a feasible alternative. Such mixing would be consistent with the trend in the $\varepsilon_{\mathrm{Nd}}$ vs. initial ${ }^{87} \mathrm{Sr} /{ }^{86} \mathrm{Sr}$ plot (Fig. 3C), although some melting of Mesoproterozoic igneous protoliths in the lower crustal section of the arc envisaged for Famatinian magmatism in general by Pankhurst et al. (2000) cannot be discounted.

The fact that the small outcrop of Las Chacras is the only place where rocks accreted to the lower crustal section of the Famatinian arc are exposed suggests that addition of juvenile material from the mantle might so far have been overlooked in the Early Ordovician evolution of the southwestern Gondwana margin, as all other exposures of the Famatinian belt in the Sierras Pampeanas represent middle to upper crust.

\section{Acknowledgements}

Financial support from Spanish MICINN grant CGL2009-07984, UCM-Santander grant GR58/08 and Argentine grant 1728 AR PICT 
Malavieille, J., Trullenque, G., 2009. Consequences of continental subduction on forearc basin and accretionary wedge deformation in SE Taiwan: insights from analogue modeling. Tectonophysics 466, 377-394.

Matzel, J.E.P., Bowring, S.A, 2004. Protolith age of the Swakane Gneiss, North Cascades, Washington: evidence of rapid underthrusting of sediments beneath an arc. Tectonics 23, TC6009. http://dx.doi.org/10.1029/2003TC001577 (18 pp.).

Mulcahy, S.R., Roeske, S.M., McClelland, W.C., Jourdan, F., Iriondo, A., Renne, P.R. Vervoort, J.D., Vujovich, G.I., 2011. Structural evolution of a composite middle to lower crustal section: the Sierra de Pie de Palo, northwest Argentina. Tectonics 30, TC1005. http://dx.doi.org/10.1029/2009TC002656.

Otamendi, J.E., Tibaldi, A.M., Vujovich, G.I., Viñao, G.A., 2008. Metamorphic evolution of migmatites from deep Famatinian arc crust exposed in Sierras Valle Fértil-La Huerta, San Juán, Argentina. Journal of South American Earth Sciences 25, 313-335.

Otamendi, J.E., Vujovich, G.I., de la Rosa, J.D., Tibaldi, A.M., Castro, A., Martino, R.D. Pinotti, L.P., 2009. Geology and petrology of a deep crustal zone from the Famatinian paleo-arc, Sierras de Valle Fértil and La Huerta, San Juan, Argentina. Journal of South American Earth Sciences 27, 258-279.

Otamendi, J.E., Ducea, M.N., Bergantz, W., 2012. Geological, petrological and geochem ical evidence for progressive construction of an arc crustal section, Sierra deValle Fértil, Famatinian Arc, Argentina. Journal of Petrology. http://dx.doi.org/10.1093/ petrology/egr079 (40 pp.).

Pankhurst, R.J., Rapela, C.W., 1995. Production of Jurassic rhyolite by anatexis in the lower crust of Patagonia. Earth and Planetary Science Letters 134, 23-36.

Pankhurst, R.J., Rapela, C.W., Saavedra, J., Baldo, E., Dahlquist, J., Pascua, I., Fanning, C.M., 1998. The Famatinian magmatic arc in the southern Sierras Pampeanas. In: Pankhurst, R.J., Rapela, C.W. (Eds.), The Proto-Andean Margin of Gondwana: Geological Society [London] Special Publication, 142, pp. 343-367.

Pankhurst, R.J., Rapela, CW., Fanning, C.M., 2000. Age and origin of coeval TTG, I- and S-type granites in the Famatinian belt of NW Argentina: transactions of the Royal Society of Edinburgh. Earth Sciences 91, 151-168.

Powell, R., Holland, T., Worley, B., 1998. Calculating phase diagrams involving solid solutions via non-linear equations, with examples using THERMOCAL. Journal of Metamorphic Geology 16, 577-588.

Ram Mohan, M., Satyarayanan, M., Santosh, M., Sylvester, P.J., Tubrett, M., Lam, R., 2012 Neoarchean suprasubduction zone arc magmatism in southern India: geochemistry, zircon U-Pb geochronology and Hf isotopes of the Sittampundi Anorthosite Complex. Gondwana Research (http://dx.doi.org/10.1016/j.gr.2012.04.004).

Ramos, V.A., 2004. Cuyania, an exotic block to Gondwana: review of an historical success and the present problems. Gondwana Research 7, 1009-1026.

Ramos, V.A., Jordan, T.E., Almendinger, R.W., Mpodozis, M.C., Kay, S.M., Cortes, J.M., Palma, M., 1986. Paleozoic terranes of the Central Argentine-Chilean Andes. Tectonics 5, 855-880.
Rapela, CW., Pankhurst, R.J., Baldo, E., Casquet, C., Galindo, C., Fanning, C.M., Saavedra, J., 2001. Ordovician metamorphism in the Sierras Pampeanas: new U-Pb SHRIMP ages in central-east Valle Fértil and the Velasco batholith. Extended Abstracts CD-ROM, South American Symposium of Isotope Geology, 3rd, Pucón, Chile, SERNAGEOMIN, pp. 616-619.

Standley, C.E., Harris, R., 2009. Tectonic evolution of forearc nappes of the active Banda arc-continent collision: origin, age, metamorphic history and structure of the Lolotoi Complex, East Timor. Tectonophysics 479, 66-94.

Straub, S.M., Zellmer, G.F., 2012. Volcanic arcs as archives of plate tectonic change. Gondwana Research 21, 495-516.

Sun, S.S., McDonough, W.F., 1989. Chemical and isotopic systematics of oceanic basalts: implication for mantle compositions and processes. In: Saunders, A.D., Norry, M.J. (Eds.), Magmatism in the Ocean Basins: Geological Society of London Special Publication, 42 , pp. 313-345.

Tera, F., Wasserburg, G., 1972. U-Th-Pb systematics in three Apollo 14 basalts and the problem of initial $\mathrm{Pb}$ in lunar rocks. Earth and Planetary Science Letters 14, 281-304.

Thomas, W.A, Astini, R.A., 2003. Ordovician accretion of the Argentine Precordillera terrane to Gondwana: a review. Journal of South American Earth Sciences 16, $67-79$.

Tracy, R.J., 1982. Compositional zoning and inclusions in metamorphic minerals. In: Ferry, J.M. (Ed.), Characterization of Metamorphism through Mineral Equilibria: Reviews in Mineralogy, 10, pp. 355-397.

Van Staal, C.R., Vujovich, G.I., Currie, K.L., Naipater, M., 2011. An Alpine-style Ordovician collision complex in the Sierra de Pie de Palo, Argentina: record of subduction of Curyania beneath the Famatina arc. Journal of Structural Geology 33, 343-361.

Viete, D.R., Hermann, J., Lister, G.S., Stenhouse, I.R, 2011. The nature and origin of the Barrovian metamorphism, Scotland: diffusion length scales in garnet and inferred thermal time scales. Journal of the Geological Society of London 168, 115-132.

Vujovich, G.I., 2011. Terreno Cuyania: escamas tectónicas y subducción tipo A. XVII Congreso Geológico Argentino, Neuquén, Abstract.

Vujovich, G.I., Miller, H., Ramos, V.A., 1994. Proterozoic metavolcanics from westem Sierras Pampeanas terrane, Argentina. Joumal of South American Earth Sciences 7, 309-323.

Williams, I.S., 1998. U-Th-Pb geochronology by ion microprobe. In: McKibben, M.A. Shanks III, W.C., Ridley, W.I. (Eds.), Applications of Microanalytical Techniques to Understanding Mineralizing Processes: Reviews of Economic Geology, 7, pp. 1-35.

Zhao, D., 2001. Seismological structure of subduction zones and its implication for arc magmatism and dynamics. Physics of the Earth and Planetary Interiors 3999, 1-18. 